\title{
INTRODUCTION OF EURO IN THE VISEGRAD COUNTRIES
}

\author{
Balázs Ferkelt ${ }^{1}$ \\ Tünde Gergics ${ }^{2}$
}

DOI: https://doi.org/10.31410/ITEMA.S.P.2019.15

\begin{abstract}
Regarding to the European Union law, all member states are obliged to introduce the euro and to make efforts to fulfil the economic and legal convergence criteria. One country of Visegrad Group, Slovakia has already introduced the common currency, while the three remaining countries, outside the euro area do not have a target date of accession yet. The aim of the study is to determine the readiness of these countries for Economic and Monetary Union membership by analysing macroand micro-level economic indicators. The Czech Republic approaches the Euro Area average for most indicators, while Hungary and Poland show significant backlogs. This paper highlights fulfilment of the inflation criterion will be the greatest challenge among the Maastricht criteria. In addition, the Visegrad countries need a detailed long-term catching-up strategy, especially for Hungary and Poland.
\end{abstract}

Keywords: Euro, Euro Area, Convergence, Visegrad Group, Visegrad Countries, Czech Republic, Hungary, Poland, Slovakia

\section{INTRODUCTION}

\begin{abstract}
A ccording to the European Union law, all member states, except the opt-out Countries (United Kingdom, Denmark), are obliged to introduce the euro and to make efforts to fulfil the economic and legal convergence criteria. There is no fixed timetable for the introduction of the euro in these countries, the European institutions do not urge the member countries. While seven out of thirteen "new EU member states" have already introduced the common currency, three countries (Bulgaria, Croatia and Romania) have indicated their intention to join last year. The three remaining Visegrad countries, outside the euro area do not have a target date of accession yet. Since joining the EU, Czech Republic and Poland have drawn up euro introduction strategies, however they have not actualized their strategies in the previous years.
\end{abstract}

The main aim of the study is to assess the readiness of these countries for Economic and Monetary Union membership by analysing macro- and micro-level economic indicators. Along with the legal and economic (nominal) convergence criteria, the study analyses the following indicators:

- gross domestic product per capita in purchasing power standards,

- the rate and balance of trade with the Euro Area,

- employment and unemployment rates,

- unit labour costs,

- general level of prices,

- development in labour productivity,

- intensity of research and development,

- current account balance.

$1 \quad$ Budapest Business School - University of Applied Sciences, Faculty of International Management and Business, Hungary

2 University of Pécs, Hungary 
Based on the analysis of these real economic indicators, the study examines the level of development of the Visegrad countries in comparison to the average data of euro area. In the case of Slovakia, the pre- and post-accession levels are presented too, while for Czech Republic, Hungary and Poland, directions of development are displayed.

Through these examinations, the paper looks for the answer to the question how much risk will introduction of euro pose for Czech Republic, Hungary and Poland. In that regard, which nominal criteria will be difficult to accomplish for these countries in the subsequent years, and what should countries do to fulfil all criteria, in addition to what time horizon should they plan with.

In economics, nominal and real convergence can be distinguished. In the European Union, nominal convergence means compliance with the Maastricht criteria, while real convergence means reducing the gap with developed countries. In this way, the structure of the article is similar, as in the first part nominal convergence and in the second part real convergence will be expounded, followed by future research directions and conclusion.

\section{FULFILLMENT OF THE CONVERGENCE CRITERIA (NOMINAL CONVERGENCE)}

All of the three Visegrad countries standing before the euro introduction display a government deficit less than 3 percent of the GDP. On top of that Czechia exhibits a budget surplus for the past three years. The fulfilment of the budget criteria will not cause any problems for the Visegrad countries. The Visegrad countries show a decreasing debt ratio, Hungary can achieve the $60 \%$ reference rate in 2022. (European Commission, 2019a) Regarding the debt ratio, the Visegrad countries show a significantly better performance than the average of euro area. The European Commission diagnosed in its Fiscal Sustainability Report that Hungary was deemed at high fiscal sustainability risk in the medium and in the long term, while Czech Republic and Poland belong in the medium term to the low risk countries and in the long term to the medium risk member states. (European Commission, 2019b)
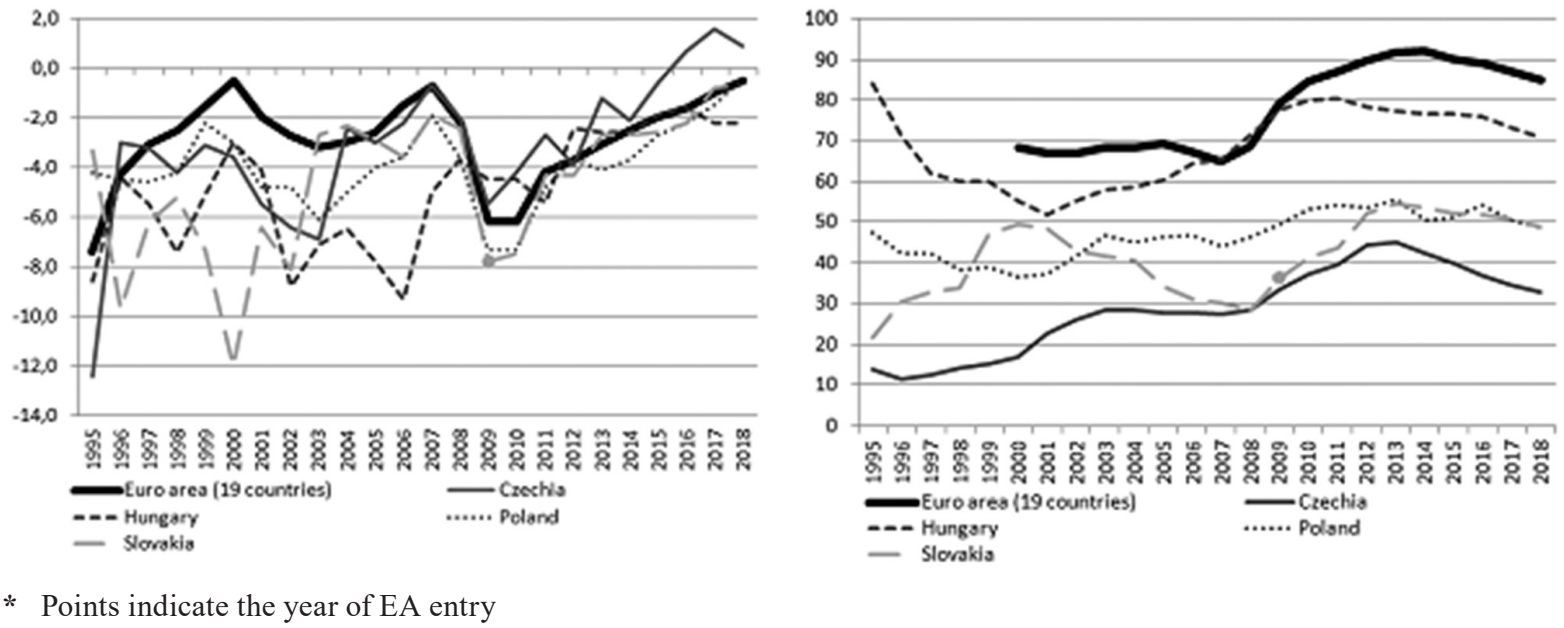

Figure 1. Government deficit/surplus (left) and Public debt (right) (percentage of GDP)

Source: based on Eurostat Database (2019A-B), own editing 

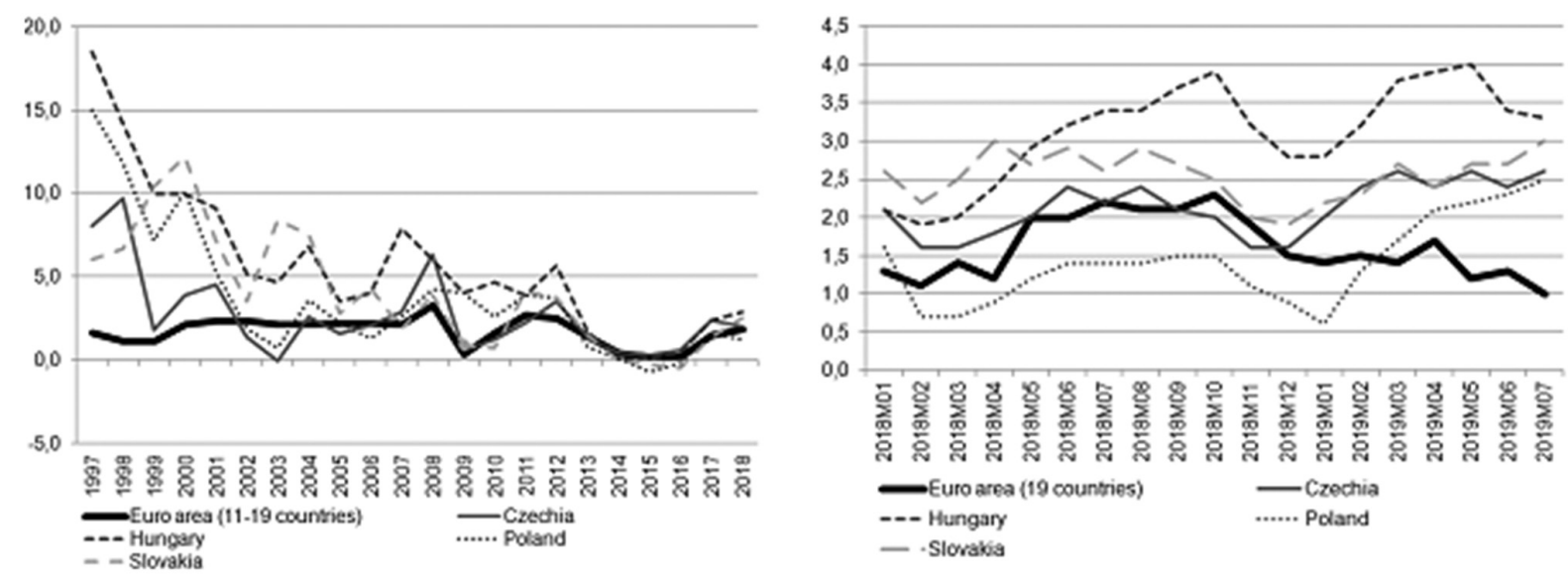

Figure 2. Annual (left) and Monthly (right) inflation (HICP $(2015=100)$, average index and rate of change)

Source: based on Eurostat Database (2019C-D), own editing

After the transition period following the regime change, the Visegrad countries could reduce the inflation rate successfully, but they have to calculate with a relatively high inflationary pressure and we suppose that the fulfilment of the inflation criteria will cause the biggest problem for this country group.

It is worth glancing at the evolution of the actual monthly inflation data. The values for the three countries vary between 2,5 and 3,3\% in May 2019. We must take into account the Balassa-Samuelson effect, as well. It was estimated in several publications, e. g. Égert (2007) defined it 1,5-2,0 \% for Hungary and Poland, Konopczak (2013) estimated 1,6-2,2\% for Czechia, 1,2$1,6 \%$ for Hungary, $1,9-3,3 \%$ for Poland, while Bauer (2015) calculated an effect less than $1 \%$ for the Country group.

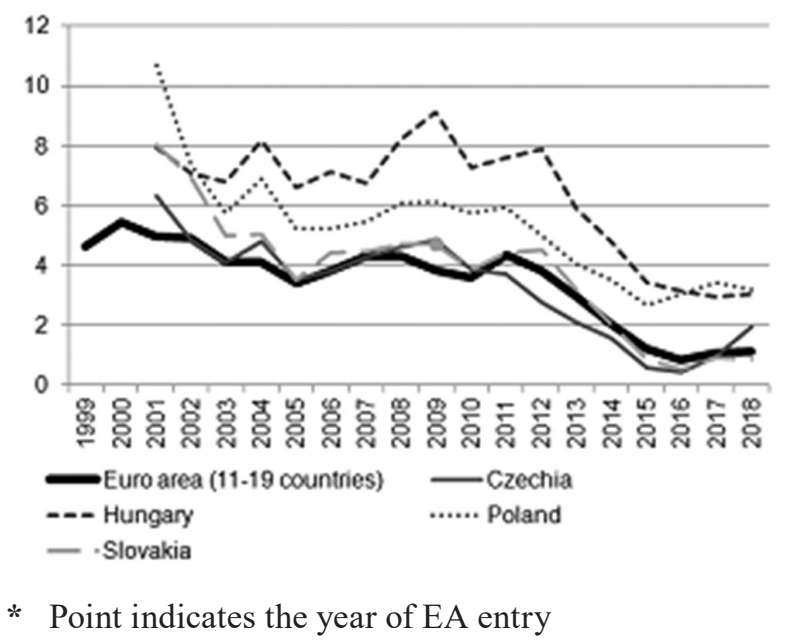

Figure 3. EMU convergence criterion bond yields (percentage, annual data)

Source: based on Eurostat Database (2019E), own editing

The interest rate of long-term bonds shows a decreasing tendency in Poland and Hungary but the bond yields are significantly higher than in the eurozone. The Czech yields were lower than in the eurozone between 2011 and 2016, but last year it showed a moderate increase. If we observe the exchange rate criterion, none of the currencies of the three Visegrad countries 
showed a fluctuation of more than 10 percent in the last two years, but they aren't members of the Exchange Rate Mechanism.

In the last two decades, the convergence criteria of Maastricht were more and more criticized, questioned. Most of criticisms intend to express the need for a certain degree of economic development beyond fulfilling the nominal convergence criteria. Accordingly, in the frame of our research we analysed some important indicators of real convergence.

\section{REAL CONVERGENCE}

The real GDP per capita data show significant disparities within the Visegrad Group and in relation to the eurozone average as well. Only Chechia is capable to overtake the level at the accession of Slovakia. The Hungarian National Bank defined a criterion for an ideal euro introduction: the GDP per capita in PPS of the country should achieve $90 \%$ of the euro area (Nagy-Virág, 2017). (In this case, Hungary would probably need more than 10 years to fulfil this criterion.)

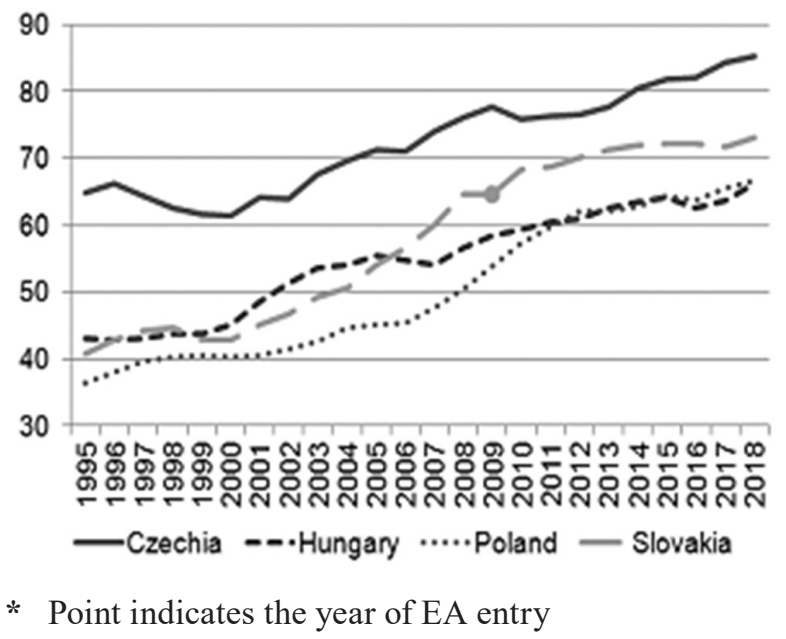

Figure 4. Real GDP per capita (in PPS, percentage of EA)

Source: based on Eurostat Database (2019F), own editing
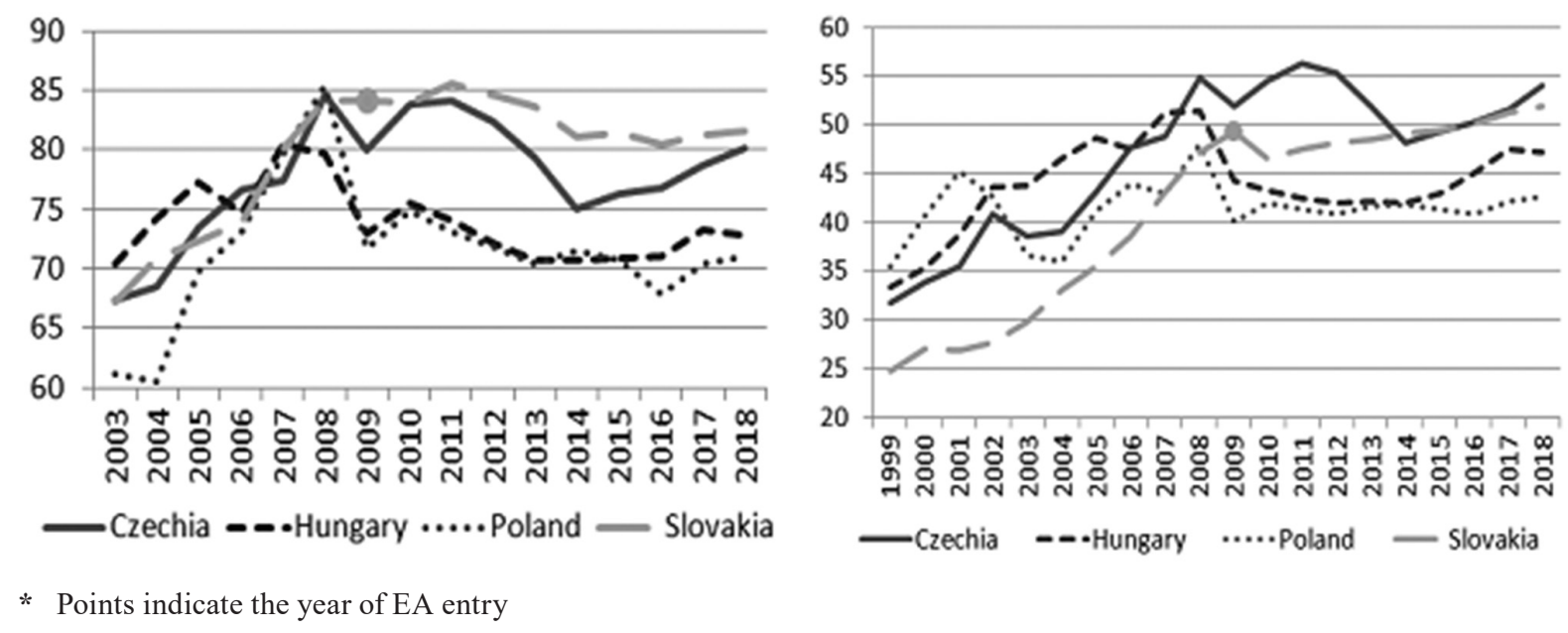

Figure 5. Price level indices - total goods (left) and total services (right) $(E A=100)$

Source: based on Eurostat Database (2019G-H), own editing 
We mentioned the possible consequences of the Balassa-Samuelson effect. The price level indices show enormous discrepancies in the field of goods and services, as well. The three Visegrad countries stand before a noticeable price level catching-up process. The differences of the price level indices in the case of the total services are more significant.
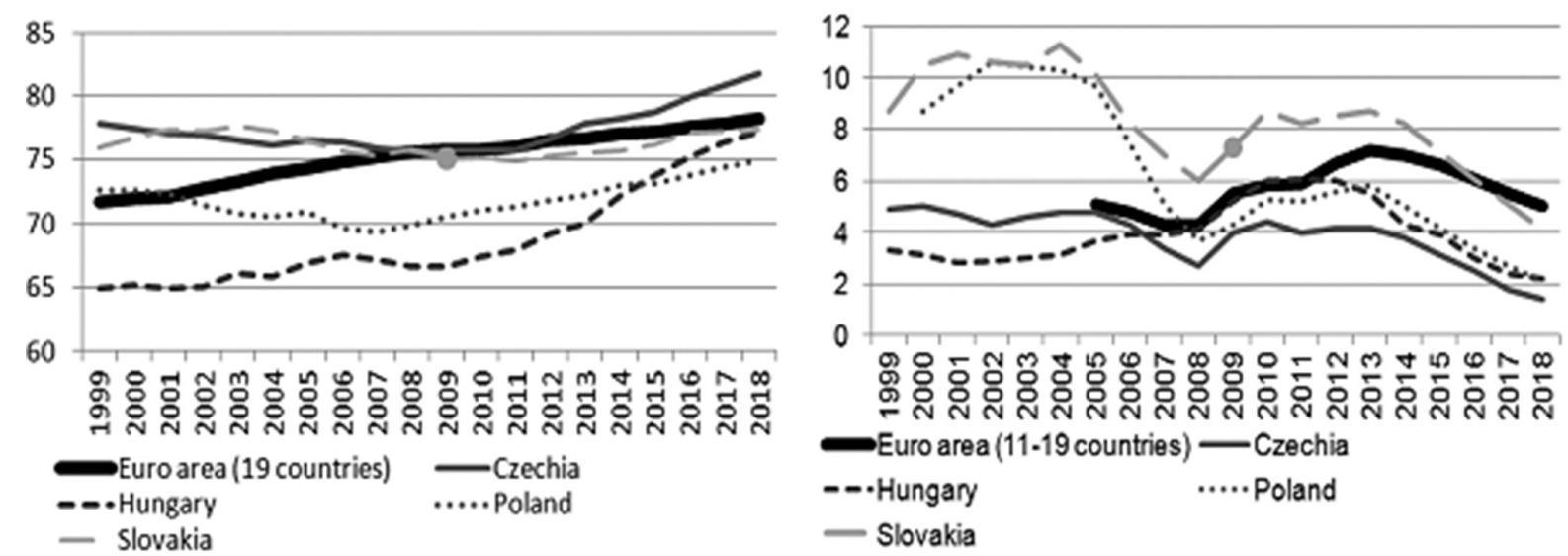

* Points indicate the year of EA entry

Figure 6. Employment rate (from 20 to 64 years, percentage of total population) (left) and Unemployment rate (percentage, LFS) (right)

Source: based on Eurostat Database (2019I-J), own editing

The labour market situation can be found as favourable in the countries, the employment rate in the population from 20 to 64 years is achieving the 75\% target of the Europe 2020 strategy. The unemployment rate shows a similar tendency, while in Czechia we can observe the shortage of labour. Regarding the labour market situation, we can't observe any disparities between the Euro area and the Visegrad countries.

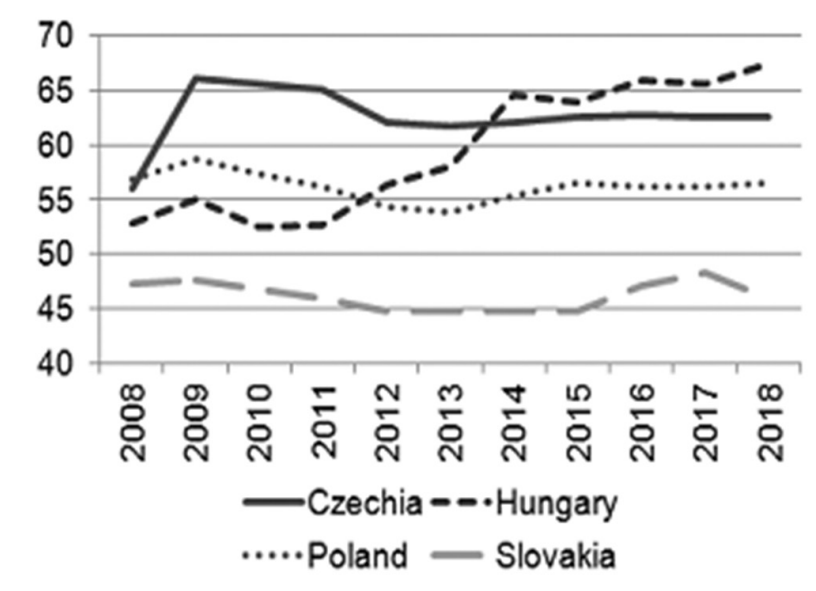

Figure 7. Share of Euro Area in exports of goods and services (percent)

Source: based on Eurostat Database (2019K), own editing

The trade integration of the three countries into the euro area is specifically strong, in all countries the share of Euro Area in exports of goods and services achieve $55 \%$, moreover in Hungary it is $67 \%$. Actually, in the eurozone Portugal shows the highest level of trade integration with $60 \%$. In 2018 all Visegrad countries displayed a positive balance of products and services with the Euro Area, especially Czechia with a surplus nearby 19 billion euro. All three countries displayed a current account balance in equilibrium in 2018, but with a decreasing surplus. 

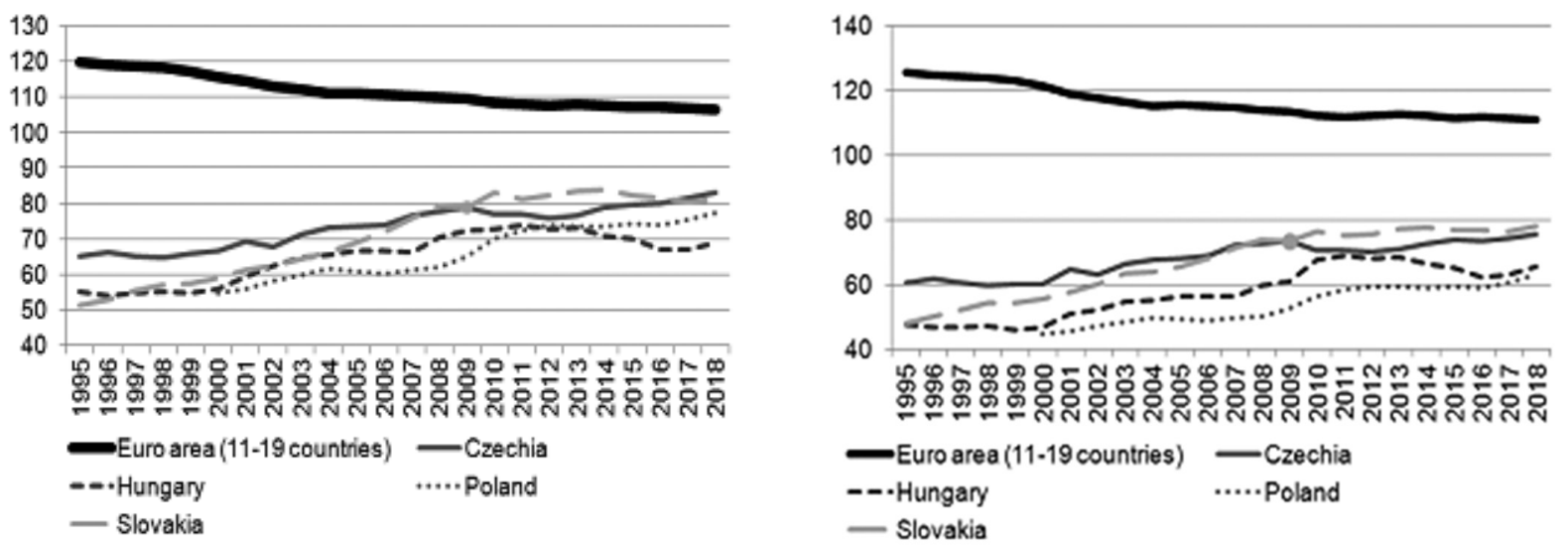

* $\quad$ Points indicate the year of EA entry

Figure 8. Nominal labour productivity per person (left) and per hour worked (right) (Percentage of EU28 total (based on million purchasing power standards), current prices)

Source: based on Eurostat Database (2019L-M), own editing

The productivity indicators show a significant discrepancy from the average of the euro area, a backlog of 25-40 percentage point. We must mention, that the discrepancy is continuously shrinking.

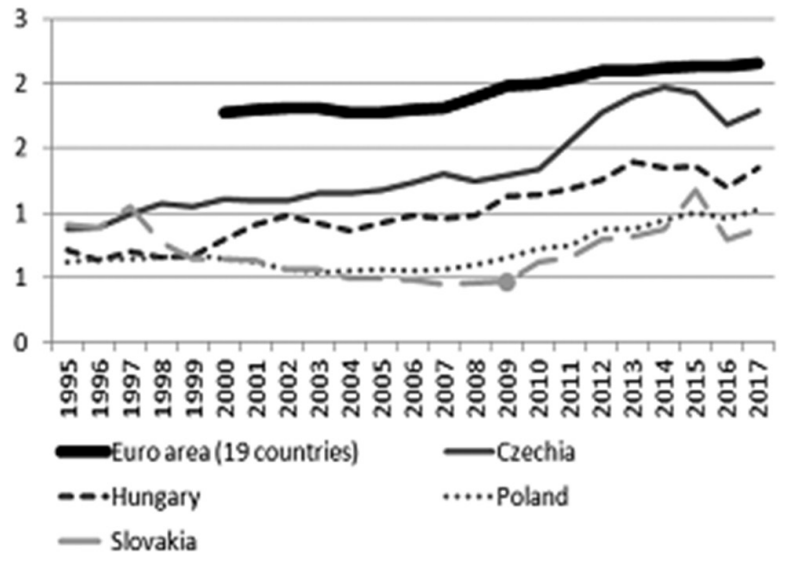

* Point indicates the year of EA entry

Figure 9. Gross domestic expenditure on R\&D (GERD, percentage)

Source: based on Eurostat Database (2019N), own editing

In all compared countries we can observe a very low-level GERD indicator. We have to add that the EU would like to achieve 3\% until 2020 (and wanted to achieve $3 \%$ until 2010, as well), while e. g. South-Korea shows $4,55 \%$.

\section{FUTURE RESEARCH DIRECTIONS}

Current research focuses exclusively on the Visegrad countries and their development compared to the euro area. In the future, it is worth expanding the research with comparative analysis of several certain Member States which had previously joined the Monetary Union. In the first place, the southern European countries (Spain, Portugal and Greece) can provide an appropriate basis for this comparison. 


\section{CONCLUSION}

Reviewing at the nominal and real convergence of the Visegrad countries, three main conclusions can be drawn in relation to the research questions raised in the introduction.

1. Based on the analysis of the real economic indicators, the Visegrad countries do not show a unified picture. The Czech Republic approaches the euro area average for most indicators, overtakes several the level of South European countries at the time of accession, while Hungary and Poland show significant backlogs. For this reason, the introduction of the euro may pose much less risks to the Czech Republic, while in the other two countries, real economic convergence in the coming years is at least as important as fulfilling the nominal criteria.

2. Due to differences in average prices and wage levels, the Balassa-Samuelson effect is expected to result in serious inflationary pressures in the Visegrad countries. Fulfilment of the inflation criterion will be the greatest challenge among the Maastricht criteria.

3. In addition to the convergence programs, the Visegrad countries need a detailed long-term catching-up strategy, especially for Hungary and Poland.

\section{REFERENCES}

Bauer, P. (2015): Az árfelzárkózás tényezői és mértékének becslése Magyarországra. MNB-tanulmányok 119. Magyar Nemzeti Bank, Budapest.

Égert, B. (2007): Real convergence, price level convergence and inflation differentials in Europe. CESifo Working Paper no. 2127.

European Commission (2019a): Hungary Convergence Programme 2019-2023 https://ec.europa. eu/info/sites/info/files/2019-european-semester-convergence-programme-hungary_hu.pdf (last time of download: 08.11.2019)

European Commission (2019b): Fiscal Sustainability Report 2018. Volume 1. Brussels

Eurostat Database (2019A): Government deficit/surplus, debt and associated data [gov_10dd_edpt1] https://appsso.eurostat.ec.europa.eu/nui/show.do?dataset=gov_10dd_edpt1\&lang=en (last update: 15.07.2019)

Eurostat Database (2019B): Government deficit/surplus, debt and associated data [gov_10dd_edpt1] http://appsso.eurostat.ec.europa.eu/nui/submitViewTableAction.do (last update: 15.07.2019)

Eurostat Database $(2019 \mathrm{C})$ : HICP $(2015=100)$ - annual data (average index and rate of change) [prc_hicp_aind] https://appsso.eurostat.ec.europa.eu/nui/submitViewTableAction.do (last update: 19.08.2019)

Eurostat Database (2019D): HICP $(2015=100)$ - monthly data (annual rate of change) [prc_hicp_ manr] https://appsso.eurostat.ec.europa.eu/nui/show.do?dataset=prc_hicp_manr\&lang=en (last update: 19.08.2019)

Eurostat Database(2019E): EMU convergence criterion series-annual data [irt_lt_mcby_a] https:// ec.europa.eu/eurostat/tgm/table.do?tab=table\&init=1\&plugin=1\&pcode=tec00097\&language $=$ en (last update: 12.08.2019)

Eurostat Database (2019F): Purchasing power parities (PPPS), price level indices and real expenditures for ESA 2010 aggregates [prc_ppp_ind] https://appsso.eurostat.ec.europa.eu/ nui/show.do?dataset=prc_ppp_ind\&lang=en (last update: 01.08.2019)

Eurostat Database (2019G): Purchasing power parities (PPPS), price level indices and real expenditures for ESA 2010 aggregates - total goods https://appsso.eurostat.ec.europa.eu/nui/ submitViewTableAction.do (last update: 01.08.2019) 
Eurostat Database (2019H): Purchasing power parities (PPPS), price level indices and real expenditures for ESA 2010 aggregates - total services https://appsso.eurostat.ec.europa.eu/ nui/submitViewTableAction.do (last update: 01.08.2019)

Eurostat Database (2019I): Employment and activity by sex and age - annual data [lfsi_emp_a] https://appsso.eurostat.ec.europa.eu/nui/show.do?dataset=lfsi_emp_a\&lang=en (last update: 10.07 .2019$)$

Eurostat Database (2019J): Unemployment by sex and age - annual average [une_rt_a] https:// appsso.eurostat.ec.europa.eu/nui/show.do?dataset=une_rt_a\&lang=en (last update: 01.08.2019)

Eurostat Database (2019K): Exports and imports by Member States of the EU/third countries [nama_10_exi]

https://appsso.eurostat.ec.europa.eu/nui/show.do?dataset=nama_10_exi\&lang=en (last update: 09.04.2019)

Eurostat Database (2019L): Labour productivity and unit labour costs [nama_10_lp_ulc] Nominal labour productivity per person https:/ec.europa.eu/eurostat/tgm/table.do?tab=table\&init=1\&plugin=1\&pcode=tec00116\&language=en (last update: 20.08.2019)

Eurostat Database (2019M): Labour productivity and unit labour costs [nama_10_lp_ulc] Nominal labour productivity per hour worked https://ec.europa.eu/eurostat/tgm/table. $\mathrm{do} ? \mathrm{tab}=$ table\&init $=1 \&$ plugin $=1 \&$ pcode $=$ tesem160\&language $=$ en (last update: 20.08 .2019 )

Eurostat Database (2019N): Gross domestic expenditure on R\&D (GERD) [T2020_20] https:// ec.europa.eu/eurostat $/ \mathrm{tgm} / \mathrm{table} . \mathrm{do} ? \mathrm{tab}=$ table\&init=1\&plugin $=1 \&$ pcode $=$ t2020_20\&language $=$ en (last update: 21.06 .2019 )

Konopczak, K. (2013): The Balassa-Samuelson effect and the channels of its absorption in the Central and Eastern European Countries. NBP Working Paper No. 163. Narodowy Bank Polski, Warszawa. https://doi.org/10.2139/ssrn.2361415

Nagy, M. - Virág, B. (2017): Felzárkózás az eurozónában - csakis megfelelö felkészültséggel teljesithetö

https://www.mnb.hu/letoltes/nagy-marton-virag-barnabas-felzarkozasi-az-eurozonaban-frissitett.pdf (last update: 03.08.2019) 